\title{
ТЕОРЕТИЧЕСКИЕ ПОИСКИ И ПРЕДЛОЖЕНИЯ
}

DOI: $10.34020 / 2073-6495-2020-4-230-242$

УДК 336.74

\section{АНАЛИЗ ДЕНЕЖНОЙ МАССЫ В РОССИИ}

\section{Смирнова Н.А.}

Международный институт дизайна и сервиса

E-mail: n.a.smirnova.1976@mail.ru

В статье исследуются изменения объема и структуры денежной массы РФ за 2011-2019 гг. Автор анализирует соответствие монетарных показателей общемировым тенденциям на основе сопоставления с аналогичными зарубежными данными. Изучение уровня коэффициента монетизации в России и экономически развитых странах позволяет автору сделать выводы о степени обеспеченности расчетов денежными средствами и перспективах развития отечественной экономики в целом.

Ключевые слова: денежная масса, денежные агрегаты, банкнота, коэффициент монетизации.

\section{ANALYSIS OF MONEY SUPPLY IN RUSSIA}

\author{
Smirnova N.A. \\ International Institute of Design and Service \\ E-mail:n.a.smirnova.1976@mail.ru
}

The article examines the changes in the volume and structure of the money supply of the Russian Federation for 2011-2019. The author analyzes the correspondence of monetary indicators to global trends on the basis of comparisons with similar foreign data. The study of the level of the monetization coefficient in Russia and economically developed countries allows the author to draw conclusions about the degree of provision of settlements with cash and prospects for the development of the domestic economy as a whole.

Keywords: money supply, monetary aggregates, banknote, monetization coefficient.

\section{ВВЕДЕНИЕ}

Денежная масса представляет собой совокупность покупательных, платежных и накопленных средств, принадлежащих физическим лицам, организациям и государству и обслуживающих хозяйственные связи между ними. На ее параметры оказывает воздействие состояние товарно-денежных отношений, особенности развития денежной системы, использование

(с) Смирнова Н.А, 2020 
передовых технологий в расчетах и т.д. Денежная масса динамична, так как постоянно изменяется и по величине, и по составу элементов. Длительное время в структуре денежной массы преобладающий удельный вес приходился на действительные полноценные деньги, и даже в начале XX в. он составлял около 40 \%. В современных условиях данный вид денег как элемент денежной массы исчез, так как золото подверглось демонетизации. Основными составляющими денежной системы выступают банкноты, монеты и средства на банковских депозитах.

Роль денежной массы в экономике является исключительно важной, ее соотношение со стоимостным объемом товаров и услуг на рынке определяет покупательную способность денег, обусловливает уровень инфляции и величину ВВП. Дискуссия мирового уровня относительно роли денег и необходимого объема денежной массы в экономике на протяжении XX в. велась между приверженцами кейнсианства $[9,11,13]$ и представителями концепции монетаризма $[10,12,14,15]$. Исследования необходимости увеличения денежной массы и проведения безналичной эмиссии весьма актуальные и в современных условиях российской экономики проводились такими отечественными экономистами, как М.И. Кротов [6], А.В. Жадобов [4], Т.А. Югай [23], В.З. Баликоев [1], В.Г. Садков [3], В.Ю. Катасонов [19].

Прошедшее десятилетие ознаменовалось существенными изменениями в российской экономике и денежно-кредитной сфере под влиянием различных факторов, что обусловливает значимость представленного в статье изучения текущих тенденций трансформации денежной массы России на предмет соответствия мировым экономическим трендам и опыту развития с учетом национальных особенностей денежного оборота. Для достижения поставленной цели был решен ряд задач: раскрыты особенности динамики и структуры денежной массы в целом и в разрезе денежных агрегатов; проведено сопоставление данных показателей с соответствующими зарубежными данными; выполнен сравнительный анализ уровня ликвидности отечественной экономики. Проведенное изыскание позволило охарактеризовать состояние монетарной сферы национальной экономики с позиции ее соответствия текущим потребностям хозяйства и достаточности средств для осуществления расчетов, а также выявить необходимые направления ее дальнейшего развития.

\section{МЕТОДОЛОГИЯ И ИНФОРМАЦИОННАЯ БАЗА ИССЛЕДОВАНИЯ}

Методологическую базу исследования составили общенаучные и специальные экономические методы, такие как статистический и сравнительный анализ, метод индукции, графический метод. Горизонтальный анализ, который заключается в сопоставлении текущих показателей денежной массы с данными предыдущих периодов, позволил оценить ее ретроспективные изменения, а также относительные отклонения ее отдельных компонентов. Вертикальный анализ дал представление об удельном весе денежных агрегатов в структуре денежной массы и их роли в платежном обороте, и его использование помогло выявить серьезные расхождения с мировыми тенденциями развития денежной массы. В дополнение к количественному ана- 
лизу расчет относительной величины монетизации экономики помогает сделать вывод об уровне эффективности использования денежной массы. Низкая величина коэффициента в сравнении с другими странами отразила недостаточность обеспеченности отечественной экономики денежными средствами.

Информационной базой для написания статьи послужили данные Банка России, Федеральной службы государственной статистики, аналитические обзоры и изыскания зарубежных и отечественных авторов. Значительные затруднения в ходе исследования возникли в связи с ограниченным количеством оперативного материала по рассматриваемой теме и несопоставимостью показателей по методике расчета при проведении сравнительного анализа. С учетом этого, а также для необходимости оценки долгосрочных изменений денежной массы и ее современного состояния период исследования охватывает 2011-2019 гг.

\section{ОЦЕНКА ИЗМЕНЕНИЙ ДЕНЕЖНОЙ МАССЫ В НАЦИОНАЛЬНОМ И МЕЖДУНАРОДНОМ АСПЕКТАХ}

Исследование изменений в денежной массе позволяет оценить ее соответствие текущим потребностям экономического развития. С целью анализа структуры и динамики денежной массы используются специальные показатели - денежные агрегаты, количество и содержание которых различается в денежных системах разных стран [18].

В настоящее время под структурой денежной массы в первую очередь понимают соотношение долей наличных и безналичных средств, находящихся в обороте. Высокий уровень развития экономики, внедрение в расчеты прогрессивных банковских технологий стимулируют увеличение удельного веса безналичных денег, который может достигать 95 \% [8, 19].

Денежная масса в национальном определении выражается денежным агрегатом М2, который состоит из наличных денег в обращении вне банковской системы (денежный агрегат М0), остатков средств в национальной валюте на расчетных, текущих и иных счетах до востребования, а также на счетах срочных депозитов и иных привлеченных на срок средств населения, нефинансовых и финансовых (кроме кредитных) организаций, являющихся резидентами Российской Федерации. В табл. 1 представлены показатели денежной массы в отечественной денежной системе $[8,16,17]$.

Анализ структуры денежной массы по данным Банка России за 20112019 гг. позволяет сделать вывод о снижении доли наличных денежных средств с 25,3 \% на 01.01.2011 г. до 19,4 \% 01.07.2019 г. и соответствующем росте удельного веса безналичных денег (с 74,7 до 80,6 \%). Также результаты расчетов отражают тренд увеличения всех денежных агрегатов (рис. 1).

Прирост агрегата М0, т.е. объема наличных средств, составивший за анализируемый период 81,6 \%, значительно отставал от изменения величины безналичной части денежной массы, темп прироста которой - 155,2 \%. Следовательно, именно безналичный компонент денежной массы, обеспечил в большей степени прирост агрегата М2 на 136,6 \%. 
Объем и структура денежной массы в России в 2011-2019 гг.

\begin{tabular}{|c|c|c|c|c|c|}
\hline Дата & $\begin{array}{c}\text { Агрегат М0, } \\
\text { млрд руб. }\end{array}$ & $\begin{array}{c}\text { Агрегат М1, } \\
\text { млрд руб. }\end{array}$ & $\begin{array}{c}\text { Агрегат М2, } \\
\text { млрд руб. }\end{array}$ & $\begin{array}{c}\text { Доля } \\
\text { наличных } \\
\text { ден М2, \% }\end{array}$ & $\begin{array}{c}\text { Доля } \\
\text { дезналичных в М2, \% }\end{array}$ \\
\hline 01.01 .2011 & 5062,7 & 10859,9 & 20011,9 & 25,3 & 74,7 \\
\hline 01.07 .2011 & 5192,8 & 10961,4 & 20721,9 & 25,1 & 74,9 \\
\hline 01.01 .2012 & 5938,6 & 12756,9 & 24204,8 & 24,5 & 75,5 \\
\hline 01.07 .2012 & 6003,9 & 12567,0 & 24461,0 & 24,5 & 75,5 \\
\hline 01.01 .2013 & 6430,1 & 13694,0 & 27164,6 & 23,7 & 76,3 \\
\hline 01.07 .2013 & 6470,3 & 13983,7 & 28212,3 & 22,9 & 77,1 \\
\hline 01.01 .2014 & 6985,6 & 15511,9 & 31155,6 & 22,4 & 77,6 \\
\hline 01.07 .2014 & 6763,5 & 14940,8 & 30073,1 & 22,5 & 77,5 \\
\hline 01.01 .2015 & 7171,5 & 15341,4 & 31615,7 & 22,7 & 77,3 \\
\hline 01.07 .2015 & 6659,5 & 15046,1 & 31958,0 & 20,8 & 79,2 \\
\hline 01.01 .2016 & 7239,1 & 16515,6 & 35179,7 & 20,6 & 79,4 \\
\hline 01.07 .2016 & 7372,7 & 16850,1 & 35856,9 & 20,6 & 79,4 \\
\hline 01.01 .2017 & 7714,8 & 17642,4 & 38418,0 & 20,1 & 79,9 \\
\hline 01.07 .2017 & 7946,9 & 18040,5 & 39623,1 & 20,1 & 79,9 \\
\hline 01.01 .2018 & 8446,0 & 19508,7 & 42442,1 & 19.9 & 80,1 \\
\hline 01.07 .2018 & 8945,5 & 20604,4 & 44126,7 & 20,3 & 79,7 \\
\hline 01.01 .2019 & 9339,0 & 21624,1 & 47109,3 & 19,8 & 80,2 \\
\hline 01.07 .2019 & 9192,8 & 21717,7 & 47349,4 & 19,4 & 80,6 \\
\hline
\end{tabular}

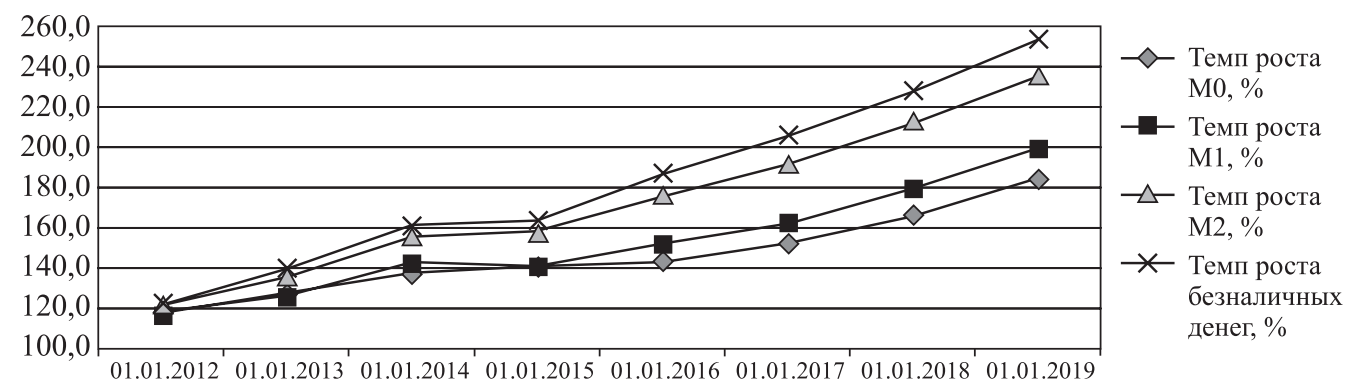

Puc. 1. Динамика объема денежной массы в 2011-2019 гг.

Более детальное структурирование денежной массы предполагает анализ долей денежных знаков разного вида и номинала в составе ее наличной части. Банкноты в каждой стране выпускаются определенного номинала, например:

- в США - 1, 2, 5, 10, 20, 50, 100 долларов;

- в Великобритании - 1, 5, 10, 20 фунтов стерлингов;

- в России - 50, 100, 200, 500, 1000, 2000, 5000 рублей.

В соответствии с расчетами, представленными в табл. 2 [8, 17], с 01.01.2011 по 01.01.2019 г. объем наличных денежных средств в обороте возрос в 1,8 раза - с 5756,4 до 10220,4 млрд руб. Прирост суммы банкнот составил 77,5 \%, однако их удельный вес уменьшился с 99,4 до 99,0 \%. Сумма монет увеличилась на 185,2 \%, а их доля увеличилась с 0,6 до 1 \%. 
Таблица 2

Объем и структура наличных денежных средств в 2011-2019 гг.

\begin{tabular}{|c|c|c|c|c|c|c|c|c|c|c|}
\hline \multirow{2}{*}{ Дата } & \multicolumn{2}{|c|}{ Банкноты } & \multicolumn{2}{c|}{ Монета } & \multicolumn{2}{c|}{ Банкноты } & \multicolumn{2}{c|}{ Монета } & \multicolumn{2}{|c|}{ Итого } \\
\cline { 2 - 12 } & $\begin{array}{c}\text { Сумма } \\
\text { млрд } \\
\text { руб.) }\end{array}$ & $\begin{array}{c}\text { Уд. } \\
\text { вес, } \\
\%\end{array}$ & $\begin{array}{c}\text { Сумма } \\
\text { млрд } \\
\text { руб.) }\end{array}$ & $\begin{array}{c}\text { Уд. } \\
\text { вес, } \\
\%\end{array}$ & $\begin{array}{c}\text { Коли- } \\
\text { чество } \\
\text { (млн } \\
\text { эк3. }\end{array}$ & $\begin{array}{c}\text { Уд. } \\
\text { вес, } \\
\%\end{array}$ & $\begin{array}{c}\text { Коли- } \\
\text { чество } \\
\text { (млн } \\
\text { эк3. }\end{array}$ & $\begin{array}{c}\text { Уд. } \\
\text { вес, } \\
\%\end{array}$ & $\begin{array}{c}\text { Сумма } \\
\text { (млрд } \\
\text { руб.) }\end{array}$ & $\begin{array}{c}\text { Коли- } \\
\text { чество } \\
\text { (млн } \\
\text { экз.) }\end{array}$ \\
\hline 01.01 .2011 & 5756,4 & 99,4 & 35,9 & 0,6 & 6345,1 & 11,7 & 47822,5 & 88,3 & 5792,3 & 54167,6 \\
\hline 01.01 .2012 & 6854,3 & 99,3 & 48,5 & 0,7 & 6315,5 & 11,0 & 51115,1 & 89,0 & 6902,8 & 57430,6 \\
\hline 01.01 .2013 & 7616,2 & 99,2 & 59,2 & 0,8 & 6492,0 & 10,7 & 54111,5 & 89,3 & 7675,4 & 60603,5 \\
\hline 01.01 .2014 & 8246,6 & 99,2 & 68,4 & 0,8 & 6433,4 & 10,1 & 57228,5 & 89,9 & 8315,0 & 63661,9 \\
\hline 01.01 .2015 & 8770,5 & 99,1 & 77,7 & 0,9 & 6592,2 & 9,8 & 60598,5 & 90,2 & 8848,2 & 67190,7 \\
\hline 01.01 .2016 & 8448,4 & 99,0 & 82,7 & 1,0 & 6212,0 & 9,0 & 62495,0 & 91,0 & 8531,1 & 68707,0 \\
\hline 01.01 .2017 & 8713,1 & 99,0 & 88,9 & 1,0 & 6085,1 & 8,6 & 64443,2 & 91,4 & 8802,0 & 70528,3 \\
\hline 01.01 .2018 & 9541,9 & 99,0 & 95,7 & 1 & 6189,1 & 8,6 & 65641,0 & 91,4 & 9547,6 & 71830,1 \\
\hline 01.01 .2019 & 10220,4 & 99,0 & 102,4 & 1 & 6262,3 & 8,6 & 66893,5 & 91,4 & 10322,8 & 73155,8 \\
\hline
\end{tabular}

Количественно наличные денежные средства возросли в 1,35 раза - с 54167,6 до 73155,8 млн экз. Количество банкнот снизилось на 1,3 \%, а их удельный вес - на 3,1 \%. Число монет увеличилось на 39,9 \%, а их доля - с 88,3 до 91,4 \% [8, 17] (рис. 2).
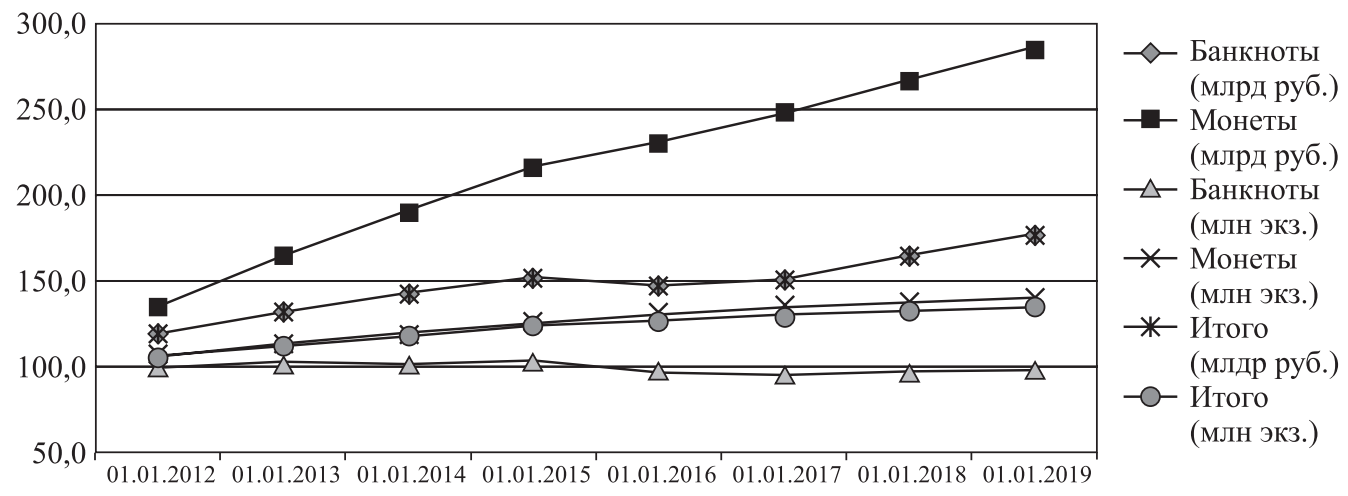

Рис. 2. Темпы роста элементов наличной денежной массы в 2011-2019 гг.

Графики динамики суммы банкнот и суммы всех наличных средств практически совпадают по причине того, что именно банкноты преобладают в наличной денежной массе в стоимостном выражении. Аналогично очень близки графики изменения количества монет и количества всех наличных денежных знаков, так как количественно в наличных средствах превалируют монеты.

На рис. 3, 4 более детально представлен удельный вес отдельных купюр в общей сумме и общем количестве банкнот.

В анализируемом периоде наибольшую долю в общей сумме банкнот занимали купюры номиналом 5000 руб.: их удельный вес возрос с 50 до 75 \% в объеме наличной денежной массы, а сумма - с 2878,2 до 7665,3 млрд руб. Вместе с тем сокращалась доля и сумма купюр более мелкого номина- 


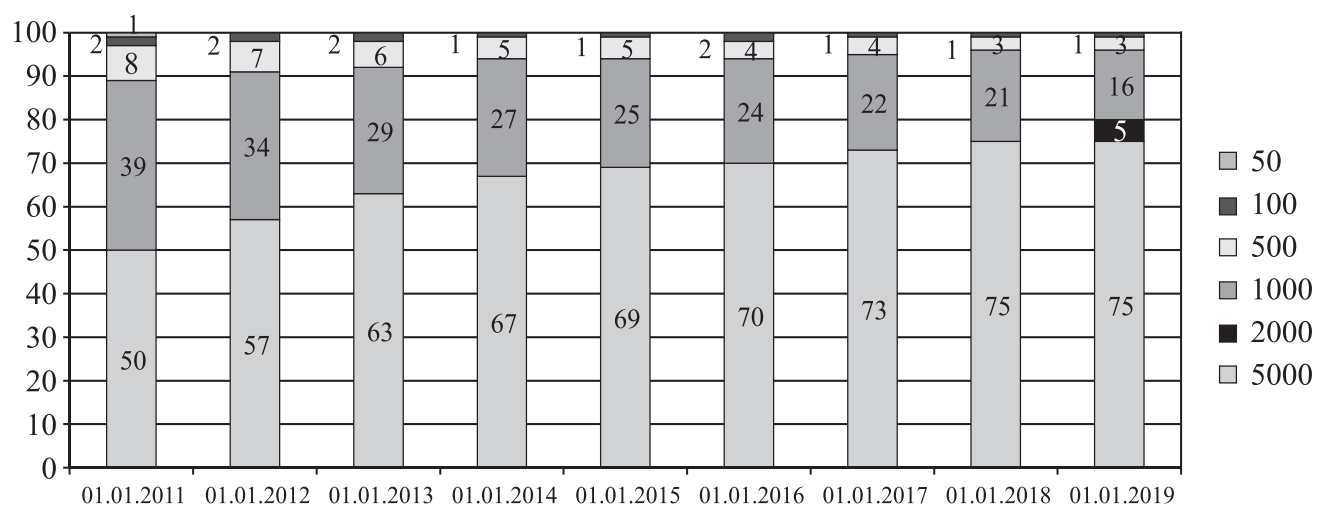

Рис. 3. Структура стоимостного объема банкнот, \%

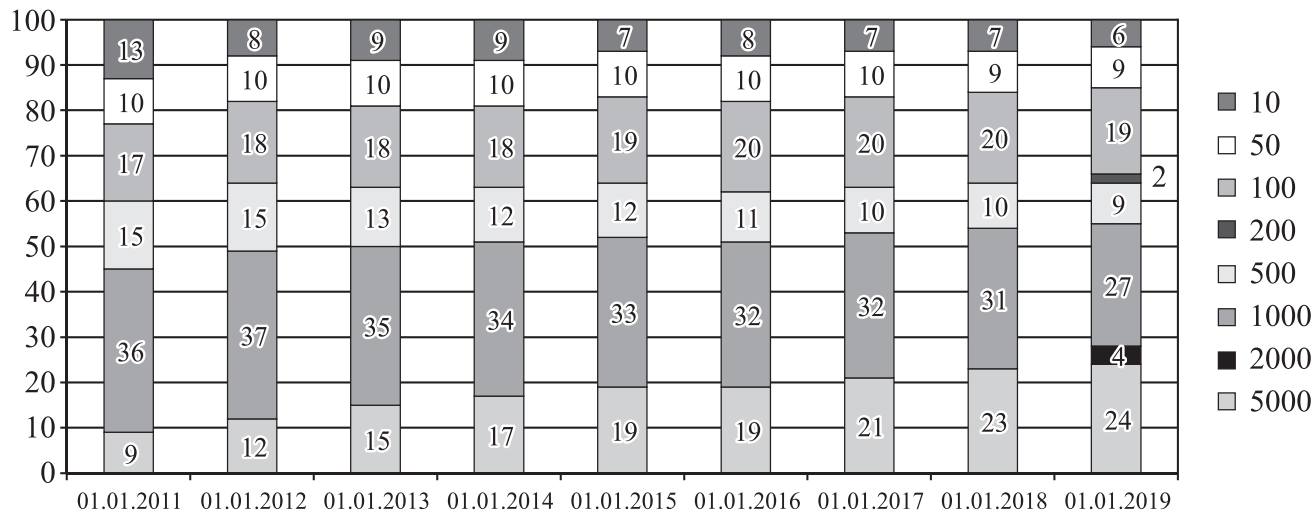

Рис. 4. Структура количественного объема банкнот, \%

ла, например, удельный вес 1000-рублевых купюр снизился с 39 до 16 \%, а стоимостной объем - с 2245 до 1635,3 млрд руб.

Структура общего количества банкнот за 2011-2019 гг. также претерпела изменения: удельный вес пятитысячных банкнот увеличился на 15 \% (с 9 до 24 \%), а их количество - с 571,1 до 1503,0 млн купюр. Существенно сократилась доля купюр номиналом в 10 руб. - с 13 до 6 \%, а также число их экземпляров - с 824,9 до 375,7 млн штук - в связи с их заменой на более износостойкие монеты того же достоинства. Кроме того, в 2019 г. 4 \% в структуре количественного объема банкнот занимали купюры в 2000 руб. и 2 \% - купюры в 200 руб. [17].

Результаты проведенного анализа денежной массы в РФ показали, что она значительно изменилась за период с 2011 по 2019 г. как в общей величине, так и структурно.

Сопоставим показатели денежной массы в РФ с аналогичными показателями других стран. В табл. 3 и 4 представлены объемы наличной части денежной массы в форме агрегата M0, выраженные в миллиардах национальных денежных единиц и миллиардах долларов США [7].

Согласно данным табл. 3 во всех рассмотренных странах наблюдался последовательный рост агрегата М0, несмотря на существенные расхождения в величине этого показателя в национальных валютах. 
Динамика агрегата М0, в млрд нац. единиц

Таблица 3

\begin{tabular}{|l|c|c|c|c|c|}
\hline \multicolumn{1}{|c|}{ Страна } & 01.01 .2011 г. & 01.01 .2013 г. & 01.01 .2015 г. & 01.01 .2017 г. & 01.01 .2019 г. \\
\hline Россия, млрд руб. & 5062,70 & 6430,10 & 7171,50 & 7714,80 & 9339,00 \\
\hline США, млрд долл. США & 891,00 & 1054,00 & 1219,00 & 1387,00 & 1608,30 \\
\hline Китай, млрд кит. юаней & 4463,00 & 5466,00 & 6026,00 & 6830,00 & 7878,30 \\
\hline Германия, млрд евро & 200,40 & 216,30 & 229,70 & 248,10 & 266,50 \\
\hline Япония, млрд яп. иен & 78400,00 & 83100,00 & 88200,00 & 97300,00 & 104583,00 \\
\hline
\end{tabular}

Динамика агрегата М0, в млрд долл. СІІА

Таблица 4

\begin{tabular}{|l|c|c|c|c|c|}
\hline \multicolumn{1}{|c|}{ Страна } & 01.01 .2011 г. & 01.01 .2013 г. & 01.01 .2015 г. & 01.01 .2017 г. & 01.01 .2019 г. \\
\hline Россия & 151,61 & 192,82 & 121,53 & 120,62 & 128,10 \\
\hline США & 891,00 & 1054,00 & 1219,00 & 1387,00 & 1608,30 \\
\hline Китай & 676,21 & 877,37 & 971,94 & 982,73 & 1145,10 \\
\hline Германия & 266,53 & 279,03 & 305,50 & 275,39 & 314,47 \\
\hline Япония & 893,14 & 1041,09 & 834,12 & 895,21 & 947,82 \\
\hline
\end{tabular}

Выражение агрегатов М0 в долларах США позволило привести их сопоставимый вид, в результате чего их объемы выровнялись до значений одного порядка. На рис. 5 представлены темпы роста М0, рассчитанные по обоим вариантам представления показателей.

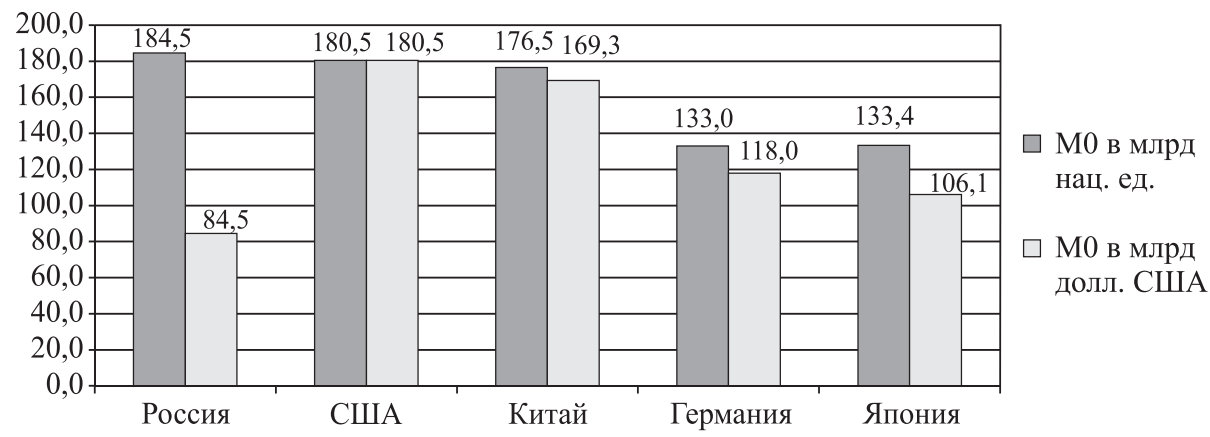

Puc. 5. Темпы роста агрегата М0 в разных странах, \%

В национальных денежных единицах агрегат М0 наиболее значительно увеличился за 2011-2018 гг. в РФ - на 84,5 \%, также существенный прирост произошел в США (на 80,5 \%) и в Китае (на 76,5 \%). В Германии и Японии агрегат возрос примерно в равной степени - на 33 и 33,4 \% соответственно. При сравнении с динамикой М0, посчитанного в долларах США, видно снижение показателей вследствие изменения обменных курсов национальных валют по отношению к американской денежной единице.

В Китае отклонение между темпами роста самое незначительное - 7,2 \%, в Германии - 15 \%, в Японии - 27,3 \%. Наиболее существенна разница в показателях динамики М0 в России: 84,5 \% составил прирост агрегата, посчитанного в рублях, и 15,5 \% - снижение М0, выраженного в долларах США. Причиной такого расхождения является отмена в конце 2014 г. интервала допустимых значений стоимости бивалютной корзины с целью перехода 
на плавающий режим валютного курса и последующее резкое снижение уровня обменного курса рубля.

Изменение агрегата М2 в 2011-2019 гг. отражено в табл. 5, 6 [16]. Как и в случае с наличными средствами стабильное увеличение показателя в национальных валютах отмечалось во всех странах.

Таблица 5

Динамика агрегата М2 в млрд нац. единиц

\begin{tabular}{|l|c|c|c|c|c|}
\hline \multicolumn{1}{|c|}{ Страна } & 01.01 .2011 г. & 01.01 .2013 г. & 01.01 .2015 г. & 01.01 .2017 г. & 01.01 .2019 г. \\
\hline Россия, млрд руб. & 20011,90 & 27164,60 & 31615,70 & 38418,00 & 47109,30 \\
\hline США, млрд долл. США & 8822,50 & 10500,10 & 11728,00 & 13292,60 & 14473,00 \\
\hline Китай, млрд кит. юаней & 72585,18 & 97414,88 & 122837,48 & 155006,70 & 182674,42 \\
\hline Германия, млрд евро & 1930,50 & 2220,40 & 2399,20 & 2755,90 & 3019,30 \\
\hline Япония, млрд яп. иен & 782300,00 & 827700,00 & 893100,00 & 956300,00 & 1014200,00 \\
\hline
\end{tabular}

Сопоставление агрегатов М2 разных стран, представленных в долларах США, отражает более существенное расхождение их объемов, чем в случае с М0: если в РФ на начало 2019 г. его величина составляла 646,2 млрд долл. США, то в Китае значение М2 на два порядка больше - 26551,5 млрд долл. США.

Динамика агрегата М2 в млрд долл. СІІА

Таблица 6

\begin{tabular}{|l|c|c|c|c|c|}
\hline \multicolumn{1}{|c|}{ Страна } & 01.01 .2011 г. & 01.01 .2013 г. & 01.01 .2015 г. & 01.01 .2017 г. & 01.01 .2019 г. \\
\hline Россия & 599,30 & 814,58 & 535,78 & 600,64 & 646,20 \\
\hline США & 8822,5 & 10500,1 & 11728 & 13292,60 & 14473,00 \\
\hline Китай & 10997,75 & 15636,42 & 19812,5 & 22303,12 & 26551,51 \\
\hline Германия & 2567,57 & 2864,32 & 3190,94 & 3059,05 & 3562,77 \\
\hline Япония & 8912,05 & 10369,58 & 8446,19 & 8798,42 & 9191,59 \\
\hline
\end{tabular}

Рис. 6 отражает относительные изменения М2 в разных странах за 20112019 гг. Можно отметить максимальные темпы роста агрегата в Китае: 251,7 \% - в юанях, 241,4 \% - в долларах США. В Германии и Японии увеличение М2 в национальных единицах опережало рост показателя в долларах США чуть более чем на $25 \%$.

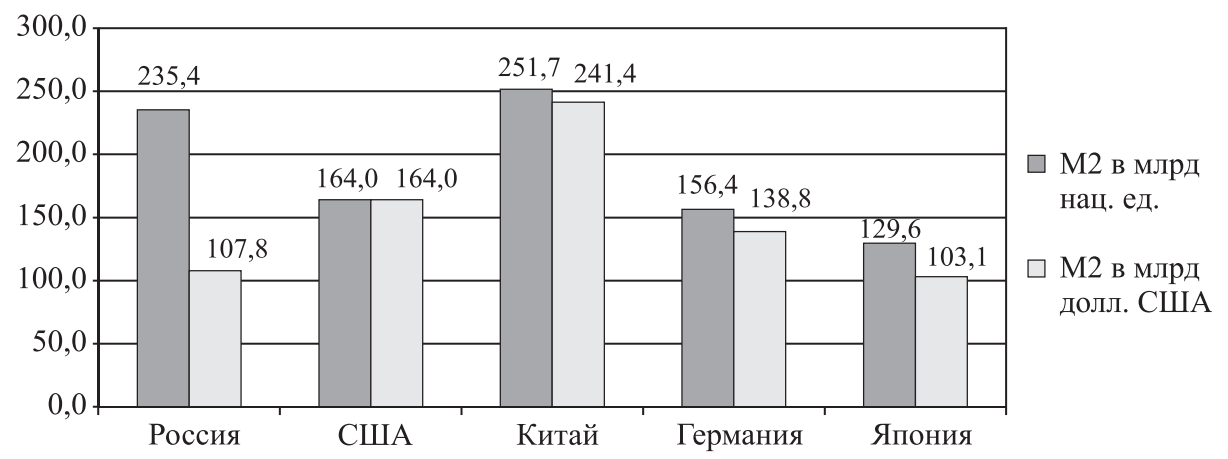

Рис. 6. Темпы роста агрегата М2 в разных странах, \% 
В РФ сложились наиболее значительные различия в темпах роста:динамика агрегата M2 в рублях в 2,2 раза больше показателя M2, выраженного в долларах США. Причина состоит также в значительном снижении обменного курса российского рубля в течение анализируемого периода.

В табл. 7 представлено изменение удельного веса наличных средств в денежной массе разных стран в 2011-2019 гг.

Таблица 7

Доля агрегата М0 в агрегате М2, \%

\begin{tabular}{|l|c|c|c|c|c|}
\hline \multicolumn{1}{|c|}{ Страна } & 01.01 .2011 г. & 01.01 .2013 г. & 01.01 .2015 г. & 01.01 .2017 г. & 01.01 .2019 г. \\
\hline Россия & 25,3 & 23,7 & 22,7 & 20,1 & 19,8 \\
\hline США & 10,1 & 10,0 & 10,4 & 10,4 & 11,1 \\
\hline Китай & 6,1 & 5,6 & 4,9 & 4,4 & 4,3 \\
\hline Германия & 10,4 & 9,7 & 9,6 & 9,0 & 8,8 \\
\hline Япония & 10,0 & 10,0 & 9,9 & 10,2 & 10,3 \\
\hline
\end{tabular}

В США произошел незначительный рост доли наличных средств с 10,1 до 11,1 \%, а в Японии - увеличение на 0,3 \%. Наименьшая доля М0 сформировалась в Китае: в начале 2011 г. она составляла 6,1 \% и снизилась к 2019 г. до 4,3 \%. В России агрегат М0 занимал в начале периода 25,3% от денежной массы и 19,8 \% на 01.01.2019 г., т.е. по сравнению с другими странами его доля существенно выше. Хотя уровень наличного денежного обращения сильно отличается в разных странах, данные расчета показали общемировой тренд роста значения безналичных средств и замещения ими наличных денег.

С целью более объективной оценки использования денежной массы в экономике целесообразно также рассмотреть значение показателя монетизации, т.е. отношение агрегата М2 к валовому внутреннему продукту (рис. 7). Значение коэффициента отражает уровень ликвидности экономики, т.е. количества денежных средств в обороте, приходящихся на один рубль валового внутреннего продукта [2, 21, 22].

Среди представленных стран наибольшее значение коэффициента монетизации экономики по итогам 2018 г. сложилось в Китае - 198 \%, что

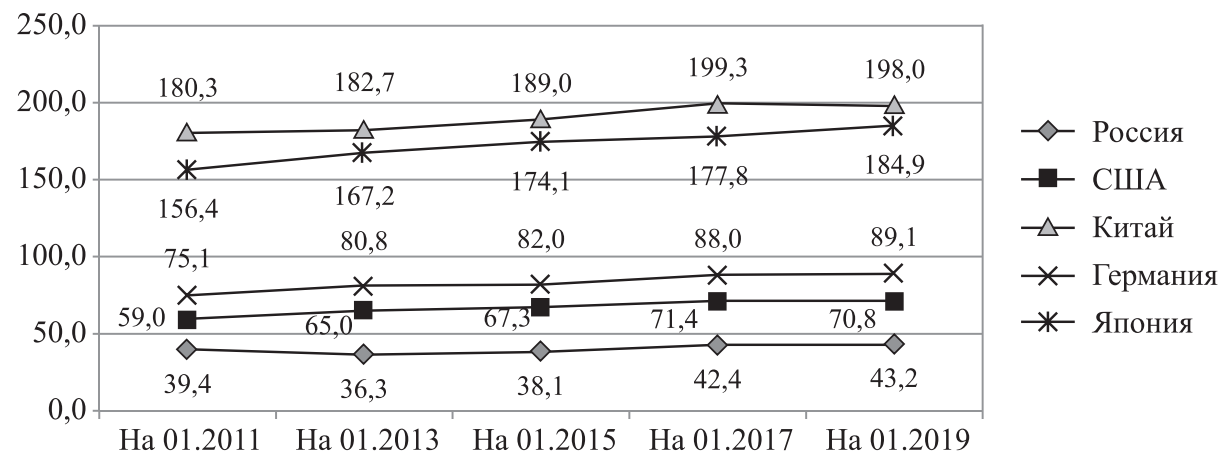

Puc. 7. Коэффициент монетизации в разных странах в 2000-2018 гг., \% 
превышает показатели развитых стран. В Японии данный показатель составил 184,5 \%. Высокая степень монетизации экономики обусловлена значительным уровнем ликвидности финансовых активов. В США и Германии величина коэффициента существенно ниже, более чем на 100 процентных пунктов: 89,1 и 70,8 \% соответственно. В России наблюдается постоянный рост показателя: с 2013 г. он возрос с 36,3 до 43,2 \%, однако эти изменения недостаточно интенсивны. Среднемировое значение коэффициента монетизации - около $125 \%$.

Единого нормативного значения коэффициента монетизации не сформировалось, однако эксперты полагают, что при величине показателя менее 50 \% высока вероятность появления денежных суррогатов и бартеризации той части экономики, которая не обслуживается денежной и банковской системой. Величина показателя более 50 \% отражает достаточность объема денежной массы для осуществления расчетов в экономике.

В этой связи целесообразно учесть мировой опыт применения инструментов денежно-кредитного регулирования с целью преодоления финансового кризиса 2008-2014 гг. Федеральная резервная система США наполняла экономику деньгами, используя количественное смягчение и снижая ставку рефинансирования для удешевления кредитных ресурсов, благодаря чему последствия кризиса были преодолены в короткие сроки. Европейский центральный банк также наращивал денежную массу, проводя эмиссию через кредитование банков по максимально доступным ставкам [23].

Банк России проводил политику кредитной рестрикции, повышая ставки, и снижал валютный курс рубля. Как следствие, усугубилась диспропорция между низким уровнем монетизации российской экономики и значительным ее насыщением долларовой массой, что перераспределяет эмиссионный доход из России в пользу США [6].

В связи со сложившейся ситуацией многие отечественные экономисты придерживаются мнения о необходимости наращивания денежной массы и повышения монетизации российской экономики. Политика кредитной экспансии поможет преодолеть спад и застой производства, снизить безработицу и темпы роста инфляции. При снижении стоимости кредитования и увеличении денежной массы возрастет функционирующий капитал и повысится уровень экономического развития [4].

Наращивание денежной массы может привести к усилению инфляции, если эмитированные средства использовать для решения текущих социальных проблем, для проведения фондовых и валютных спекуляций, а для стимулирования роста непосредственно производства. Поэтому процесс реализации денежной эмиссии должен быть тщательно подготовлен с целью минимизации всех рисков, а дополнительную денежную массу следует направлять в реальный сектор экономики и на финансирование высокотехнологичных инновационных проектов $[2,5,6]$.

Таким образом, мировая практика и отечественный опыт показывают, что обеспечение экономического рывка невозможно в экономике с низким коэффициентом монетизации, поэтому при сохранении в экономике и монетарной сфере России текущего положения вероятность значительных позитивных изменений остается невысокой. 


\section{ВЫВОДЫ}

Проведенный анализ денежной массы за 2011-2019 гг. позволяет сформулировать ряд заключений.

1. Объем денежной массы в России, выраженный в национальных денежных единицах, возрос в 2,4 раза, причем большую долю этого прироста обеспечил безналичный компонент. В стоимостной структуре наличных средств преобладают банкноты, доля которых составила 99 \%, а в количественной структуре - монеты с удельным весом 91,4 \%.

2. При выражении денежных показателей в долларах США их динамика показала сокращение наличных средств на 15,5 \% и прирост агрегата М2 на 7,8 \%, что существенно ниже аналогичных показателей в большинстве других стран, с которыми проводилось сопоставление, и вызвано двукратным снижением обменного курса рубля по отношению к доллару США в 2014-2015 гг.

3. Доля наличных средств в денежной массе в России снизилась за период на 5,5 \%, но остается почти вдвое выше, чем в других странах. Причины такого расхождения могут быть связаны, во-первых, с историческими традициями денежного оборота в нашей стране с акцентом на использование населением банкнот и монет, что сформировало соответствующий «платежный менталитет», особенно у граждан старшего возраста; во-вторых, с потребностью технического сопровождения операций по безналичным расчетам на обширной территории и необходимостью вложения финансовых ресурсов для развития необходимой банковской инфраструктуры. Преодоление данных препятствий возможно на основе повышения финансовой грамотности населения и развития мобильного банкинга.

4. Коэффициент монетизации экономики в России возрос на 3,8 \% и составил на начало 2019 г. 43,2 \%, что в пять раз ниже, чем в Китае и вдвое, чем в Германии. Данный уровень монетизации отечественной экономики отражает недостаточный объем средств для расчетов. Последовательное снижение значения ключевой ставки Банка России в 2015-2019 гг. (с 17 до 6,5 \%) [20] создает предпосылки увеличения денежной массы на основе повышения доступности кредитных ресурсов. При этом для ограничения роста уровня инфляции необходимо параллельное повышение объемов производства товаров с высокой добавленной стоимостью для потребления на внутреннем рынке, и, следовательно, соответствующее увеличение потребительского спроса и платежеспособности населения. В этом случае денежные средства будут неоднократно участвовать в производственном цикле до того, как трансформируются в доходы непосредственных потребителей, что весьма понижает риски возникновения инфляции спроса $[1,3]$.

Таким образом, изменения в денежной массе России в целом соответствуют общемировым тенденциям в монетарной сфере, однако достигнутые значения основных показателей в настоящее время не являются достаточными и требуют дальнейшей корректировки.

\section{Литература}

1. Баликоев В.З. Современная экономика России: М. Фридман против Дж. Кейнса // Вестник Томского государственного университета. Экономика. 2018. № 42. C. 6-21. 
2. Баликоев В.З. Уровень монетизации экономики России: поиск оптимума // Вестник НГУЭУ. 2017. № 1. С. 118-133.

3. Греков И.Е., Садков В.Г. Об оптимальном уровне инфляции с позиции результатов общественного развития // Финансы и кредит. 2007. № 6 (246). С. 2-11.

4. Жадобов А.В. Ложная дилемма: эмиссия или кризис // Приволжский научный вестник. 2015. № 6-3 (46). С. 15-20.

5. Кайгородиев $A$.A. Повышение уровня монетизации российской экономики как фактор экономического роста // Научное обозрение. Экономические науки. 2019. № 3. С. 11-14.

6. Кротов М.И., Мунтиян В.И. Об антикризисной монетарной стратегии экономического развития России // Проблемы современной экономики. 2015. № 3 (55). C. 17-26.

7. Россия и страны мира. 2018 год: статистический сборник / Росстат. М., 2018. 375 с.

8. Смирнова Н.А. Денежная система современной России / Монография. Челябинск: Изд-во ЧОУВО МИДИС, 2018. 138 с.

9. Самуэльсон П., Нордхаус В. Экономика. М.: Вильямс, 2014. 1360 с.

10. Фишер И. Покупательная сила денег: её определение и отношение к кредиту, проценту и кризисам / пер. с англ. М.: Дело, 2001. 320 с.

11. Хикс Дж.Р. Стоимость и капитал / пер. с англ. М.: Прогресс, 1993. 488 с.

12. Friedman M. Money and Economic Development. New York: Praeger Publishers, 1973.

13. Keynes J.M. The General Theory of Employment, Interest and Money // The Collected Writings of John Maynard Keynes. Cambridge University Press, 2012.

14. Marshall A. Money, Credit, and Commerce. Prometheus Books, 2003.

15. Brunner K., Meltzer A.H. Money and the Economy: Issues in Monetary Analysis Cambridge University Press, 1997.391 p.

16. Денежная масса, денежные агрегаты, динамика денежной массы в России и по странам. [Электронный ресурc]. URL: https://prognostica.info/news/show/9 (дата обращения: 10.11.2019).

17. Денежная масса (национальное определение). [Электронный ресурc]. URL: https://cbr.ru/statistics/ms/ (дата обращения: 10.11.2019).

18. Денежные агрегаты. [Электронный ресурc]. URL: https://www.banki.ru/wikibank/ denejnyie_agregatyi/ (дата обращения: 10.11.2019).

19. Катасонов B.Ю. Мир наличных денег на перепутье. [Электронный ресурс]. URL: https://svpressa.ru/economy/article/229825/ (дата обращения: 15.11.2019).

20. Ключевая ставка Банка России. [Электронный ресурc]. URL: https://cbr.ru/hd_ base/keyrate/ (дата обращения: 10.11.2019).

21. Коэффициент монетизации экономики, динамика в России и странах 05.06.2019. [Электронный pecypc]. URL: https://prognostica.info/news/show/38 (дата обращения: 15.11.2019).

22. Монетизация экономики. [Электронный ресурc]. URL: https://www.banki.ru/ wikibank/ monetizatsiya_ekonomiki/ (дата обращения: 15.11.2019).

23. Югай Т.А., Фунг Т.Д. Мировой опыт использования центральными банками инструментов денежно-кредитного регулирования в условиях финансового кризиса 2008-2014 годов // Интернет-журнал «Науковедение» 2014. № 6. [Электронный pecypc]. URL: http://naukovedenie.ru/PDF/119EVN614.pdf (дата обращения: 15.11.2019).

\section{Bibliography}

1. Balikoev V.Z. Sovremennaja jekonomika Rossii: M. Fridman protiv Dzh. Kejnsa // Vestnik Tomskogo gosudarstvennogo universiteta. Jekonomika. 2018. № 42. P. 6-21.

2. Balikoev V.Z. Uroven' monetizacii jekonomiki Rossii: poisk optimuma // Vestnik NGUJeU. 2017. № 1. P. 118-133. 
3. Grekov I.E., Sadkov V.G. Ob optimal'nom urovne infljacii s pozicii rezul'tatov obshhestvennogo razvitija // Finansy i kredit. 2007. № 6 (246). P. 2-11.

4. Zhadobov A.V. Lozhnaja dilemma: jemissija ili krizis // Privolzhskij nauchnyj vestnik. 2015. № 6-3 (46). P. 15-20.

5. Kajgorodcev A.A. Povyshenie urovnja monetizacii rossijskoj jekonomiki kak faktor jekonomicheskogo rosta // Nauchnoe obozrenie. Jekonomicheskie nauki. 2019. № 3. P. 11-14.

6. Krotov M.I., Muntijan V.I. Ob antikrizisnoj monetarnoj strategii jekonomicheskogo razvitija Rossii // Problemy sovremennoj jekonomiki. 2015. № 3 (55). P. 17-26.

7. Rossija i strany mira. 2018 god: statisticheskij sbornik / Rosstat. M., 2018. 375 p.

8. Smirnova N.A. Denezhnaja sistema sovremennoj Rossii / Monografija. Cheljabinsk: Izd-vo ChOUVO MIDIS, 2018. 138 p.

9. Samujel'son P., Nordhaus V. Jekonomika. M.: Vil'jams, 2014.1360 p.

10. Fisher I. Pokupatel'naja sila deneg: ejo opredelenie i otnoshenie k kreditu, procentu i krizisam / per. s angl. M.: Delo, 2001.320 p.

11. Hiks Dzh.R. Stoimost' i kapital / per. s angl. M.: Progress, 1993. 488 p.

12. Friedman M. Money and Economic Development. New York: Praeger Publishers, 1973.

13. Keynes J.M. The General Theory of Employment, Interest and Money // The Collected Writings of John Maynard Keynes. Cambridge University Press, 2012.

14. Marshall A. Money, Credit, and Commerce. Prometheus Books, 2003.

15. Brunner K., Meltzer A.H. Money and the Economy: Issues in Monetary Analysis Cambridge University Press, 1997.391 p.

16. Denezhnaja massa, denezhnye agregaty, dinamika denezhnoj massy v Rossii i po stranam. [Jelektronnyj resurs]. URL: https://prognostica.info/news/show/9 (data obrashhenija: 10.11.2019).

17. Denezhnaja massa (nacional'noe opredelenie). [Jelektronnyj resurs]. URL: https://cbr. $\mathrm{ru} / \mathrm{statistics} / \mathrm{ms} /$ (data obrashhenija: 10.11.2019).

18. Denezhnye agregaty. [Jelektronnyj resurs]. URL: https://www.banki.ru/wikibank/ denejnyie_agregatyi/ (data obrashhenija: 10.11.2019).

19. Katasonov V.Ju. Mir nalichnyh deneg na pereput'e. [Jelektronnyj resurs]. URL: https:// svpressa.ru/economy/article/229825/ (data obrashhenija: 15.11.2019).

20. Kljuchevaja stavka Banka Rossii. [Jelektronnyj resurs]. URL: https://cbr.ru/hd-_base/ keyrate/ (data obrashhenija: 10.11.2019).

21. Kojefficient monetizacii jekonomiki, dinamika v Rossii i stranah 05.06.2019. [Jelektronnyj resurs]. URL: https://prognostica.info/news/show/38 (data obrashhenija: 15.11. 2019).

22. Monetizacija jekonomiki. [Jelektronnyj resurs]. URL: https://www.banki.ru/wikibank/ monetizatsiya_ekonomiki/ (data obrashhenija: 15.11.2019).

23. Jugaj T.A., Fung T.D. Mirovoj opyt ispol'zovanija central'nymi bankami instrumentov denezhno-kreditnogo regulirovanija v uslovijah finansovogo krizisa 2008-2014 godov // Internet-zhurnal «Naukovedenie» 2014. № 6. [Jelektronnyj resurs]. URL: http:// naukovedenie.ru/PDF/119EVN614.pdf (data obrashhenija: 15.11.2019). 